\title{
肝転移を伴う胃癌の治療
}

\author{
神戸大学第 1 外科 \\ 中江 史朗 中村 毅 井上 和則 \\ 加藤 道男 斉藤 洋一 \\ 国立神戸病院外科 \\ 多 淵 芳 樹
}

\section{TREATMENT FOR GASTRIC CANCER PATIENTS WITH SYNCHRONOUS LIVER METASTASIS}

\section{Siro NAKAE, Takeshi NAKAMURA, Kazunori INOUE Michio KATOH and Yoichi SAITOH}

lst Department of Surgery, Kobe University School of Medicine

Yoshiki TABUCHI

Department of Surgery, National Kobe Hospital

\begin{abstract}
最近16年間に教室で経験した肝転移を伴う胃癌74例を対象とし，治療法と転㷌の関連を検討し，延 命効果の点から治療方針につき検討した。原発巣切除例の転帰は非切除例より良好な傾向 $(\mathbf{p}<0.1)$ がみられたが, 原発巣切除のみの $\mathrm{H}_{1}$ 症例と原発巣技よび肝転移切除例（すべて $\mathrm{H}_{1}$ 症例）の間では転 㷌に有意差はみられなかった。非切除例は試験開腹と造瘦術の間ならびに化学療法施行例と化学療法 非施行例の間で転㷌に差は認められなかった。 ずれも切除化学療法施行例であった，以上より肝転移胃癌に対しては積極的に原発巣を切除した上で 化学療法を行う方針をとれば，治療成績の向上が期待できると考党られる.
\end{abstract}

索引用語：胃癌, 肝転移

はじめに

胃癌の診断技術が著しく向上した今日に扔いても肝 転移を来した後に発見される胃癌は全胃癌の 5.5〜14.5\%を占めており，このような症例に対してい かなる治療方針で臨めばよいか困難を感じる場合も少 なくない. 今回, 教室で経験した肝転移を伴う胃癌症 例（以下同時性肝転移症例之略）の治療法と転㷌との 関連を詳細に分析し, 治療効果 (延命効果) といら点 からその治療方針について検討を加えたので，若干の 文献的考察を加兊て報告す。

検討対象と方法

昭和 43 年 1 月から昭和 58 年 12 月までの 16 年間に教室 で経験した胃癌1,264例のうち, 同時性肝転移症例は

$<1986$ 年 4 月 9 日受理 $>$ 別刷請求先：中江 史朗 厂664 伊丹市南野中曾根 138
106例（8.4\%）であった。このうち開腹により肝転移 程度を確認しえた症例は94例であり，これらの症例よ り術死 4 例（術死亡 $4.3 \%$ ）と消息不明 7 例（消息判明 率92.6\%) 扛よび免疫療法単独施行例 9 例（症例が少 なく詳細な転帰解析が不可能であるために免疫療法例 は除外した。)を除いた74例を検討対象とした。これら の症例の治療概要は表 1 の通り切除例は41例（手術単 独例21例, 化学療法併用例20例), 非切除例は33例(手 術単独症例14例, 化学療法併用例19例) であった。 化学療法は MMC 30mg・Tegaful 60g (5FU 30g) 以上投与例を化学療法例 (以下化療例と略) とし, こ の規準以下の投与例ならびに化学療法が行われていな い症例を化学療法非施行例（以下非化療例と略）とし た. 転帰解析は癌死例の平均生存期間と生存率で行い, 前者は $\mathrm{t}$ 検定・後者は $\chi^{2}$ 検定で，また生存率曲線の差 の検定は Generalized Wilcoxon test で行った. 背景 
表 1 胃癌肝転移症例の治療概要

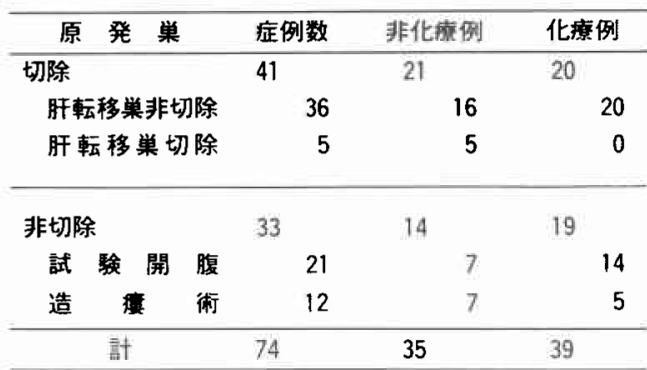

因子は転帰に重大な影響を及ぼすと考学られる胃癌取 扱い規約 ${ }^{1)}$ によ分類した肝転移程度 $\left(\mathrm{H}_{1}, \mathrm{H}_{2}, \mathrm{H}_{3}\right)$ ・ 浆膜浸潤程度 $\left(\mathrm{S}_{0}, \mathrm{~S}_{1}, \mathrm{~S}_{2}, \mathrm{~S}_{3}\right)$ ・腹膜播種性転移の有無 $(\mathrm{P}(-), \mathrm{P}(+)) \cdot$ リンパ節転移程度 $\left(\mathrm{N}_{0}, \mathrm{~N}_{1}, \mathrm{~N}_{2}, \mathrm{~N}_{3}\right.$, $\mathrm{N}_{4}$ ) について治療法別に解析し，その差の検定は $\chi^{2}$ 検 定（必要に応じ Fisherの直接確率計算法）で行った。

\section{結果}

I. 非化療 (手術単独) 例の治療法別治療成績

まず原発巣の切除による延命効果（切除効果と略） の有無を検討するために，非化療症例のうち，非切除 症例 $(n=14)$ と原発巣切除・肝転移巣非切除症例 $(n=$ 16）の転帰を比較検討した，原発巣切除・肝転移巣非 切除例の生存率曲線は非切除例上り良好な傾向（ $z=$ $1.81, \mathrm{p}<0.1$ ) が認められた（図 1 上）。生存率では， 原発巣切除・肝転移巣非切除例の 6 力月生存率は $37.5 \%$ で非切除例の7.1\%に比べて良好な傾向（p< $0.1)$ がみられ，さらに切除例の 9 力月生存率 $31.3 \%$ は 非切除例の $0 \%$ より有意に（p<0.05）良好であっ た。平均生存期間は原発巣切除・肝転移单非切除例は $5.8 \pm 4.1$ 力 月で, 非切除例 $3.2 \pm 1.8$ 力より有意に $(\mathrm{t}=2.3, \mathrm{p}<0.05)$ 良好であり，最長生存期間も後者は 13.5 力月で前者の 6.2 力より良好であった（表 2 ）。

肝転移巣の切除効果に関して，原発巣切除・肝転移 巣切除例 $\left(n=5\right.$, 全例 $H_{1}$ 症例） と原発巣切除・肝転移 巣非切除の $H_{1}$ 症例 $(n=4)$ の転帰を比較した。肝転移 巣切除例の生存率曲線は肝転移巣非切除例上りも若干 良好であったが, 有意の差はみられなかった(図 1 下)。 また平均生存期間と最長生存期間は，肝転移巣切除例 は肝転移巣非切除例より良好であったが，両者の平均 生存期間には統計学的に有意な差はみられなかった (表 2 ).

治療法別に背景因子を検討寸ると（表 3 ), 非切除例 は原発䉓切除・肝転移巣非切除例に比べ $\mathrm{S}_{3}$ の症例の割
図 1 非化療例の生存率
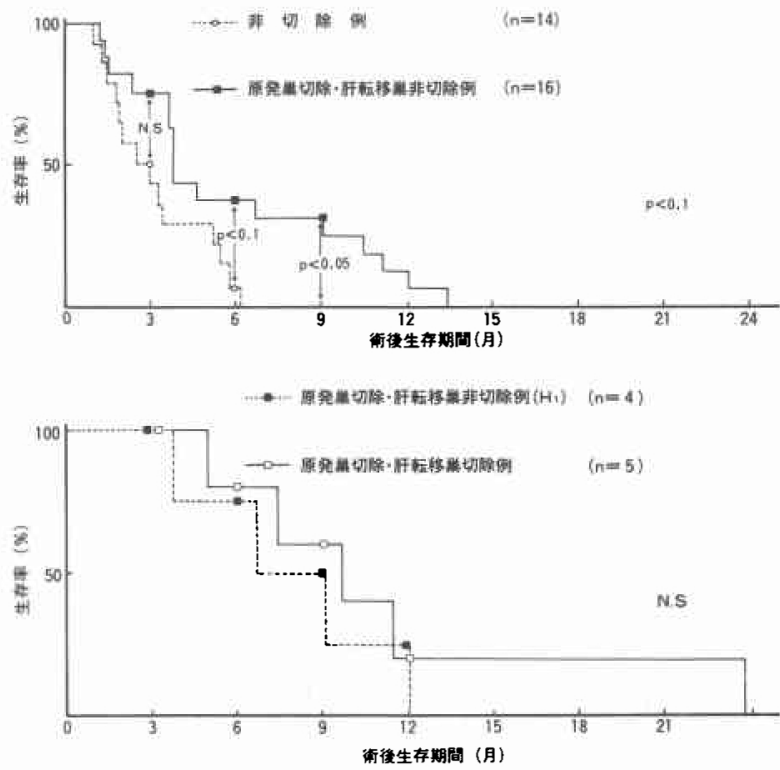

表 2 非化療例の平均生存期間と最長生存期間

\begin{tabular}{|c|c|c|c|c|c|}
\hline \multirow{2}{*}{ 治 } & \multirow{2}{*}{ N) } & \multirow{2}{*}{ 非切鉒 } & \multicolumn{3}{|c|}{ 原発监切除 } \\
\hline & & & 旰軽移等非切除 & 肝転移紧非切馀H， & 的输移巣切除 \\
\hline \multicolumn{2}{|c|}{$\begin{array}{c}\text { 平均生在月数 } \\
\text { (又士丶万.D.) }\end{array}$} & $3.2 \pm 1.8$ & $\leftarrow p<0.05 \rightarrow 5.8 \pm 4.1$ & $7.9 \pm 3.5 \leftarrow$ N.S $\rightarrow$ & $11.5 \pm 7.3$ \\
\hline \multicolumn{2}{|c|}{ 褧生存月数 } & 6.2 & 13.5 & 12.1 & 23.8 \\
\hline
\end{tabular}

表 3 非化療例の背景因子

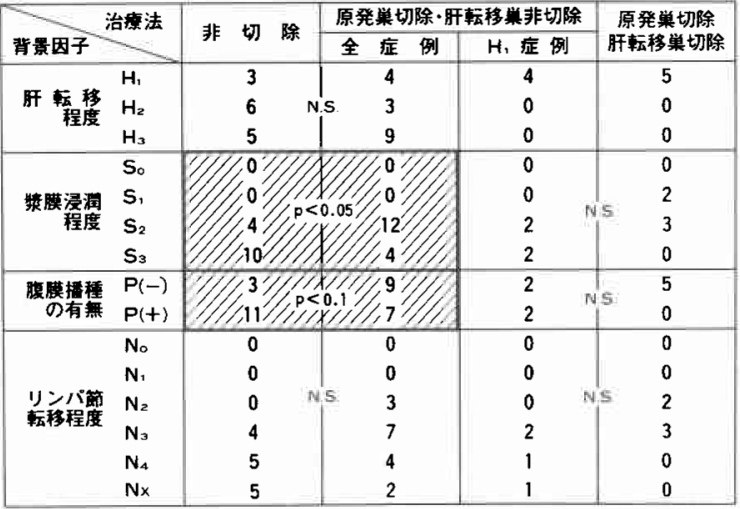

合が高 $<\left(x^{2}=4.74, \mathrm{p}<0.05\right)$, 腹膜播種性転移女非切 除例に多い傾向（p<0.1）があったが，肝転移程度と リンパ節転移程度には有意な差はみられなかった。原 発巣切除・肝転移巣非切除の $\mathrm{H}_{1}$ 症例之原発巣切除・肝 転移巣切除例の背景因子は, 浆膜漫潤の程度・腹膜播 種性転移の有無・リン八゚節転移程度の何れについても 
その分布に有意の差はみられなかった。

II. 化療例の治療法別治療成績

化療例を非切除例 $(n=19)$ と原発巣切除・肝転移巣 非切除例 $(n=20)$ に分類し，その治療成績を検討した。 原発巣切除・肝転移巣非切除例の生存率曲線は非切除 例の生存率曲線より。有意に $(z=3.37, \mathrm{p}<0.01)$ 良好 であった（図 2).

非切除例はすべて癌死していたが，原発巣切除・肝 転移巣非切除例には 4 例の生存症例（4 力月生存， 4 年 6 力月生存, 7 年 2 力月生存, 11 年 1 力月生存) が

図 2 化療例の生存率

- $\rightarrow$ (

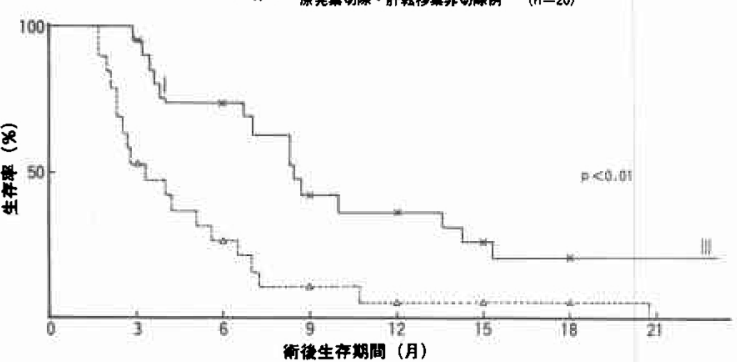

表 4 化療例の平均生存期間之最長生存期間

\begin{tabular}{|c|c|c|c|}
\hline 治 滰 法 & 非切除 & & 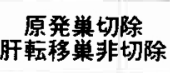 \\
\hline $\begin{array}{c}\text { 平均生存月 数 } \\
(x \pm S . D .)\end{array}$ & $5.0 \pm 4.5$ & $\leftarrow p<0.05 \rightarrow$ & $9.0 \pm 6.1$ \\
\hline 最長生存月数 & 20.8 & & 133.0生存中 \\
\hline
\end{tabular}

表 5 化療例の背景因子

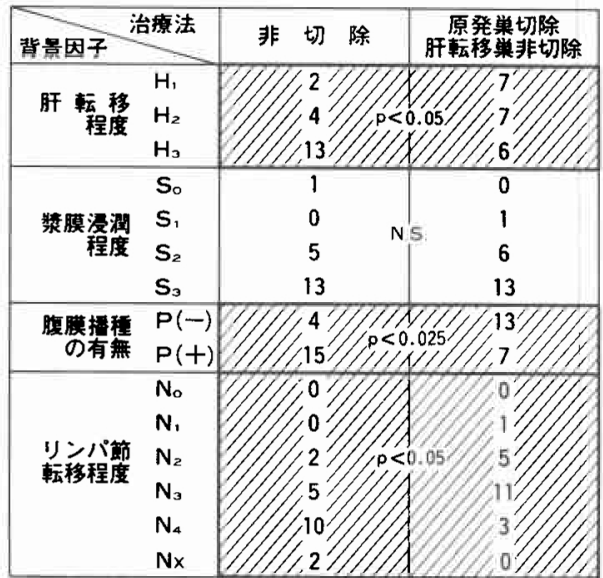

あり，この 4 例を除いた治療法別の平均生存期間と最 長生存期間を検討すると表 4 のと招り，原発巣切除・ 肝転移巣非切除例の平均生存期間は非切除例上り有意 に $(\mathrm{t}=2.24, \mathrm{p}<0.05)$ 良好であり, 最長生存期間は非 切除例では20.8力月であったのに対し，原発巣切除・ 肝転移巣非切除例では 11 年 1 力月, 7 年 2 力月, 4 年 6 カ月の 3 例の長期生存例があった.

背景因子を検討すると(表 5 ), 非切除例と原発巣切 除例との間に肝転移程度・腹膜播種性転移の有無, リ ン八節転移程度に分布の差 $\left(\chi^{2}=6.15, \mathrm{p}<0.05 \cdot \chi^{2}=\right.$ $5.97, \mathrm{p}<0.025 \cdot \chi^{2}=8.12, \mathrm{p}<0.05 ）$ が認められ，非 切除例は切除例よりも進行程度が高い症例が多かっ た.

III. 非切除例の治療法別治療成績

非切除例を単開腹例 (試験開腹, $\mathrm{n}=21$ ) と胃空腸吻 合や胃㾇造設術などの造㾇術例 $(\mathrm{n}=12)$ に分けて転帰 を検討すると, 図 3 上のと括り単開腹例之造㜢術例の 生存率には汪とんど差 $(z=1.37$, N.S. $)$ はみられなかっ

図 3 非切除例の生存率
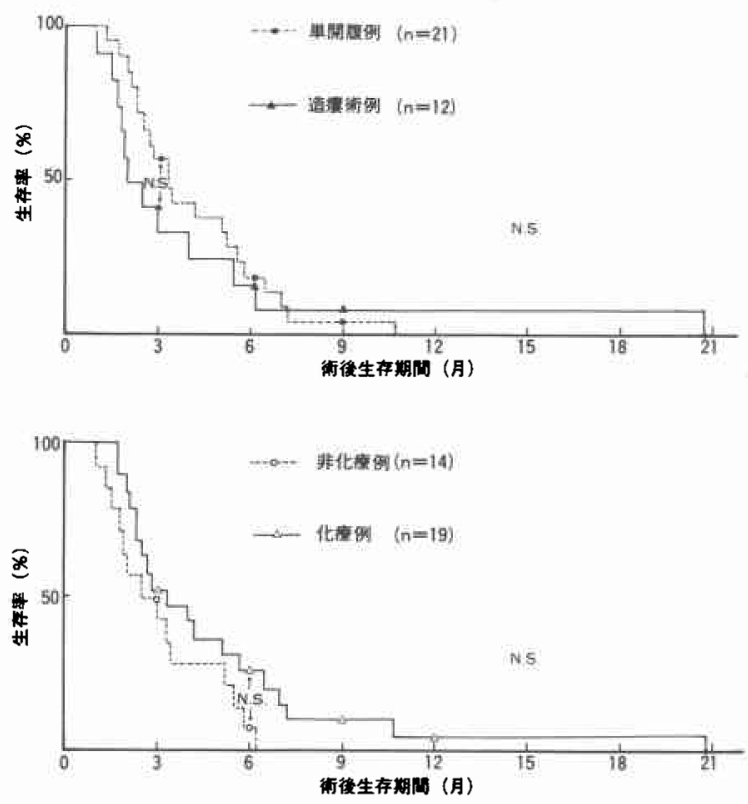

表 6 非切除例の平均生存期間と最長生存期間

\begin{tabular}{|c|c|c|c|c|c|}
\hline 治 & 裳 法 & 単開腹 & 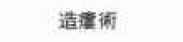 & 非化意 & 化辣 \\
\hline \multicolumn{2}{|c|}{$\begin{array}{c}\text { 平均生存月数 } \\
\text { (又场.D.) }\end{array}$} & $4.1 \pm 2.4$ & $\leftarrow$ N.S. $\rightarrow 4.3 \pm 5.4$ & $3.2 \pm 1.8$ & $\leftarrow$ N.S. $\rightarrow 5.0 \pm 4.5$ \\
\hline \multicolumn{2}{|c|}{ 最長生存月数 } & 10.7 & 20.8 & 6.2 & 20.8 \\
\hline
\end{tabular}


た.

非切除例はすべて癌死していたが，治療法別の平均 生存期間招よび最長生存期間では，単開腹例 $4.1 \pm 2.4$ 力月と造瘦術例 $4.3 \pm 5.4$ 力月の間 $(t=0.13$, N.S. $)$ 並 びそ非化療例 $3.2 \pm 1.8$ 力月之化療例 $5.0 \pm 4.5$ 力月の間 $(\mathrm{t}=1.58$, N.S.) には統計学的に有意な差はみられな かった（表 6 ).

背景因子の検討（表 7 ）では単開腹例と造瘦術例の 間，化療例と非化療例の間には肝転移程度・浆膜浸潤 程度・腹膜播種性転移の有無・リンパ節転移程度の何 れの因子に招いても統計的に有意な差はみられなかっ た。

IV. 原発巣切除・肝転移巣非切除例の治療法別治療 成績

化学療法の効果を原発巣切除・肝転移巣非切除の非 化療例（n=16）と化療例（n=20）の生存率曲線・生 存率・平均生存期間 - 最長生存期間について比較検討 した。

生存率曲線では化療例は非化療例より有意に（ $\mathrm{z}=$ $2.12, p<0.05 ）$ 良好であった（図 4）。

非化療例はすべて癌死していたが，化療例には 4 例

表 7 非切除例の背景因子

\begin{tabular}{|c|c|c|c|c|c|c|}
\hline 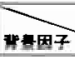 & 治篧法 & 单開腹 & 造㧧衐 & 非化澺 & & 化 綦 \\
\hline \multirow{3}{*}{ 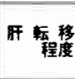 } & $H_{1}$ & 2 & 3 & 3 & \multirow{3}{*}{ NS } & 2 \\
\hline & $\mathrm{H}_{2}$ & 7 & 3 & 6 & & 4 \\
\hline & $\mathrm{H}_{3}$ & 2 & 6 & 5 & & 13 \\
\hline \multirow{4}{*}{ 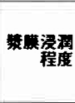 } & So & 1 & 0 & 0 & \multirow{4}{*}{ ns } & 1 \\
\hline & S, & 0 & 0 & 0 & & 0 \\
\hline & $S_{2}$ & 7 & 2 & 4 & & 5 \\
\hline & $\mathrm{S}_{3}$ & 13 & 10 & 10 & & 13 \\
\hline \multirow{2}{*}{ 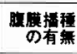 } & $P(-)$ & 5 & 1 & 3 & \multirow[t]{2}{*}{ NS } & 4 \\
\hline & $P(t)$ & 15 & 11 & 11 & & 15 \\
\hline \multirow{6}{*}{ 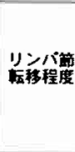 } & $N_{0}$ & 0 & 0 & 0 & \multirow{6}{*}{$N$} & 0 \\
\hline & $\mathrm{N}$, & 0 & 0 & 0 & & 0 \\
\hline & $\mathrm{N}_{2}$ & 2 & 0 & 0 & & 2 \\
\hline & $\mathrm{N}_{3}$ & 5 & 4 & 4 & & 5 \\
\hline & $\mathbf{N}_{4}$ & 9 & 6 & 5 & & 10 \\
\hline & $\mathrm{Nx}$ & 5 & 2 & 5 & & 2 \\
\hline
\end{tabular}

図 4 原発巣切除・肝転移巣非切除例の生存率

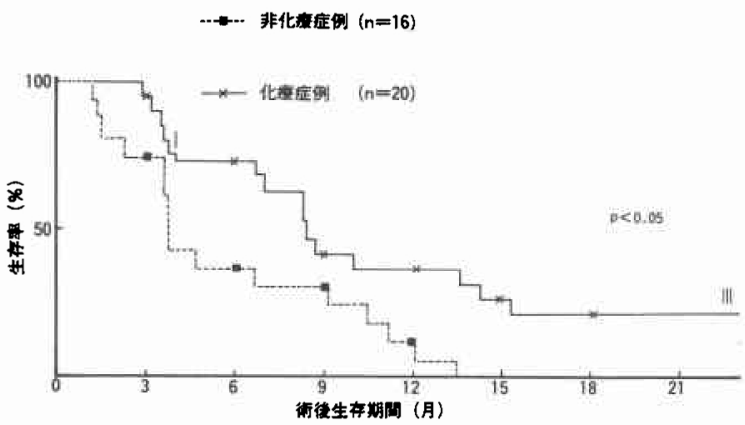

の生存例（後述）があった。この生存例 4 例を除いた 平均生存期間と最長生存期間を比較検討した（表 8 ）.

平均生存期間は化療例 $9.0 \pm 6.1$ 力月は非化療例 $5.8 \pm 4.1$ 力月より良好な傾向 $(\mathrm{t}=1.73, \mathrm{p}<0.1)$ が認 められた.非化療例の最長生存期間は 13.5 力であり, 化療例では生存中の 4 例のうち 3 例が 4 年 6 力月以上 生存中(11年 1 力月, 7 年 2 力月, 4 年 6 力月)であっ た。

背景因子を検討すると, 肝転移程度・腹膜播種性転 移の有無・リンパ節転移程度では分布に有意な差はみ られなかったが，浆膜浸潤程度は両者の間の分布に有 意な差 $\left(\chi^{2}=7.41, \mathrm{p}<0.025\right)$ がみられ，化療例は非化 療例に比べて $\mathrm{S}_{3}$ 症例が多く, $\mathrm{S}_{2}$ 症例が少なかった。

V. 長期生存例

術後 4 年以上の生存例は 3 例 $(4.1 \%, 3 / 74)$ で全例 原発巣切除・肝転移巣非切除例で，なんらかの形で化 学療法が行われていた。11年 1 力月生存中の症例は60 歳の男性, $\mathrm{S}_{2} \mathrm{P}_{0} \mathrm{H}_{2} \mathrm{~N}_{1} \mathrm{~A}$ 後小 2 型胃癌の症例で, 幽門 側普通切除が施行され術中肝動脈より MMC $8 \mathrm{mg}$ 術 後肝動脈より $5 \mathrm{FU}$ 計 $2,000 \mathrm{mg}$ が投与されていた. 7 年

表 8 原発巣切除 - 肝転移巣非切除例の平均生存期間 と最長生存期間

\begin{tabular}{lccc}
\hline 治 法 & 非化撞 & 化療 \\
\hline $\begin{array}{c}\text { 平均生存月数 } \\
(\bar{x} \pm \text { S.D.) }\end{array}$ & $5.8 \pm 4.1$ & $\leftarrow p<0.1 \rightarrow 9.0 \pm 6.1$ \\
\hline 最長生存月数 & 13.5 & 133.0 生存中
\end{tabular}

表 9 原発巣切除・肝転移巣非切除例の背景因子

\begin{tabular}{|c|c|c|c|c|c|c|c|}
\hline 背景因子 & 台滰法 & 非 & 化 & & & 化 & 療 \\
\hline \multirow{3}{*}{$\begin{array}{l}\text { 肝転移 } \\
\text { 程度 }\end{array}$} & $\mathrm{H}_{1}$ & \multicolumn{3}{|c|}{4} & \multirow{3}{*}{ NS } & \multicolumn{2}{|r|}{7} \\
\hline & $\mathrm{H}_{2}$ & & 3 & & & \multicolumn{2}{|r|}{7} \\
\hline & $\mathrm{H}_{3}$ & \multicolumn{3}{|c|}{9} & & \multicolumn{2}{|r|}{6} \\
\hline 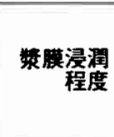 & $\begin{array}{l}S_{0} \\
S_{1} \\
S_{2} \\
S_{3}\end{array}$ & \multicolumn{6}{|c|}{ 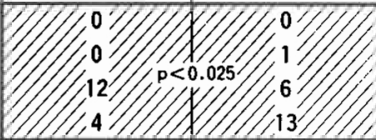 } \\
\hline \multirow{2}{*}{ 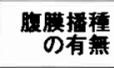 } & $P(-)$ & & 9 & & \multirow{2}{*}{ N.S } & \multicolumn{2}{|r|}{13} \\
\hline & $P(+)$ & & 7 & & & & 7 \\
\hline \multirow{6}{*}{ 当ン年答 } & $N_{\circ}$ & & 0 & & \multirow{6}{*}{$\mathbb{N}:$} & & 0 \\
\hline & $N_{1}$ & & 0 & & & & 1 \\
\hline & $\mathrm{N}_{2}$ & & 3 & & & & 5 \\
\hline & $N_{3}$ & & 7 & & & & 11 \\
\hline & $\mathrm{N}_{4}$ & & 4 & & & & 3 \\
\hline & $\mathrm{Nx}$ & & 2 & & & & 0 \\
\hline
\end{tabular}


表10 術後 4 年以上の長期生存例

\begin{tabular}{|c|c|c|c|c|c|c|c|c|}
\hline 年令 & 性 & 手術所見 & 部位 & 肉眼型 & 手術 & 化学療注 & & 枟㷌 \\
\hline 60 & 男 & $\mathrm{S}_{2} \mathrm{~N}_{1} \mathrm{P}_{0} \mathrm{H}_{2}$ & A後小 & 2 型 & $\begin{array}{l}\text { 幽 門 側 } \\
\text { 普通切除 }\end{array}$ & $\left\{\begin{array}{ll}\text { MMC } & 8 \mathrm{mg} \\
5 \mathrm{Fu} & 2 g\end{array} \mid\right.$ & 肝针注 & 11年 1 力月生存中 \\
\hline 50 & 男 & $\mathrm{S}_{3}$ (結膈) $\mathrm{N}_{3} \mathrm{P}_{1} \mathrm{H}_{3}$ & MA後大 & 1 型 & $\begin{array}{l}\text { 盟 門 側 } \\
\text { 垔 全 摘 }\end{array}$ & $\left(\begin{array}{ll}\text { MMC } & 10 \mathrm{mg} \\
\text { MMC } & 36 \mathrm{mg} \\
\text { FT207 } & 16.8 \mathrm{~g}\end{array}\right\}$ & $\begin{array}{l}\text { 肝重柱 } \\
\text { 全身投与 }\end{array}$ & 7 年 2 力月生存中 \\
\hline 62 & 女 & $\mathrm{S}_{1} \mathrm{~N}_{3} \mathrm{P}_{0} \mathrm{H}_{2}$ & AM周 & 2 型 & $\begin{array}{l}\text { 幽 門 側 } \\
\text { 蓄通切除 }\end{array}$ & $\left(\begin{array}{ll}M M C & 24 \mathrm{mg} \\
5 \mathrm{Fu} & 500 \mathrm{mg}\end{array}\right\}$ & 全身投与 & 4 年 6 力月生存中 \\
\hline
\end{tabular}

2 力月生存中の症例は 50 歳男性, $\mathrm{S}_{3}$ (結腸) $\mathrm{P}_{1} \mathrm{H}_{3} \mathrm{~N}_{3}$ MA 後大 1 型の胃癌症例で, 幽門側亜全摘が施行され 術中肝動脈より MMC $10 \mathrm{mg}$, 術後末㮐静脈より $\mathrm{MMC}$ 計 $36 \mathrm{mg}$, Tegaful $800 \mathrm{mg} /$ day 21 日間投与さ れた症例であり, 術後 7 年 2 力月後の CT および超音 波検查では肝転移巣は消失して打り，肉体的制限を受 けることなく社会復帰している，4年 6 力月生存中の 症例は62歳の女性, $\mathrm{S}_{1} \mathrm{P}_{0} \mathrm{H}_{2} \mathrm{~N}_{3} \mathrm{AM}$ 周 2 型の胃癌症例 で，幽門側普通切除が施行され，術後末梢静脈より $\mathrm{MMC}$ 計 $24 \mathrm{mg}, 5 \mathrm{FU}$ 計 $500 \mathrm{mg}$ を投与された症例で 4 年 6 カ月以後の消息は不明となっている.

な和以上 3 例のうち 11 年 1 力月生存例拉よび 4 年 6 力月生存例は術中の肉眼的診断により肝転移陽性子判 定したが, 7 年 2 カ月生存例に関しては術中 biopsy に て肝転移陽性を組織学的に確認している。

\section{考 察}

胃癌の診断技術が向上した今日においても，な和同

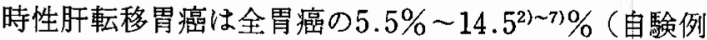

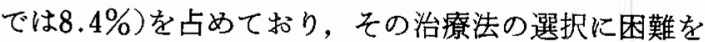
感じる場合も少なくない，自験の同時性肝転移の治療 法と転㷌との関連を詳細に分析して，その延命効果と い5点から同時性肝転移胃癌の治療方針について検討 を加点た。

同時性肝転移胃癌においては，肝転移巣を切除しな くても原発巣を切除した方が切除しない場合よりも予 後が良好であること，すなわち切除効果が得られるで

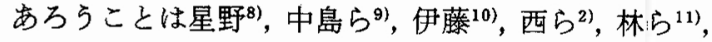

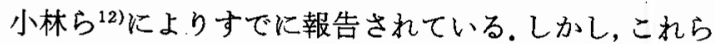
の報告では予後に大きな影響を及ぼす切除例と非切除 例の原発巣の状態や補助療法の有無などの背景因子に ついて言及されていない点で問題が残されている。著 者らは自験の胃癌肝転移例について原発巣切除による 延命効果すなわち切除効果を, 非化療例(手術単独例)
を対象に転帰解析を行らと同時に背景因子に関しても 検討を加光た。

自験の切除例之非切除例の背景因子では, 肝転移程 度とリンパ節転移程度の分布に差はみられなかった が, 非切除例には浆膜漫潤程度の高度な例之腹膜播種 性転移例が多いといら相違がみられた。転㷌に関して は，切除例は非切除例上り る平均生存期間之 9 力月生 存率は有意に $(\mathrm{p}<0.05)$ 良好であり, 切除例の生存率 曲線は非切除例上り良好な傾向 $(\mathrm{p}<0.1)$ が 又られ, 切除例の転帰は非切除例上り良好であった。背景因子 が異っているためにこの結果から直ちに同時性肝転移 胃癌に切除効果があるとは言学ないが，可能な限り原 発単を切除することによって延命が期待できそうであ る.

同時性肝転移胃癌における肝合併切除の治療成績に 関しても伊藤 ${ }^{13)}$, 白鳥 $ら^{4)}$, 樺木野ら ${ }^{14)}$, 中西ら ${ }^{15}$ に上 りすでに報告されており，これらの報告の治療成績を 概括寸ると, 肝合併切除は肝転移胃癌の $5 \sim 15 \%$ に行 われその平均生存期間は $9 \sim 26.5$ 力之報告されてい る. 自験例では106例の胃癌肝転移例に対し 6 例(肝合 併切除率 $5.7 \%$ ) に肝合併切除が行われていた。 その平 均生存期間は 11.5 力で, 最長生存期間は 23.8 力月 諸家の報告とほぽ一致した成績であった。しかし，自 験の肝転移巣切除例はすべて $\mathrm{H}_{1}$ 症例 $\left(\mathrm{H}_{1} \mathrm{P}_{0} \mathrm{~S}_{0-2} \mathrm{~N}_{0-3}\right)$ であったので, 肝転移巣非切除の $\mathrm{H}_{1}$ 症例と比較した が両者の間には 3 から24力月の生存率・生存率曲線な らびに平均生存期間のいずれにおいても有意な差はみ られず, 肝合併切除の転帰は非合併切除例より若干良 好であったに過ぎなかった。 中西ら ${ }^{15)}$ ，奥山ら ${ }^{16)}$ は $\mathrm{H}_{1}$ または $\mathrm{H}_{2}$ で $\mathrm{P}_{0} \sim \mathrm{P}_{1}$ 以下の症例に対しては肝転移巣合 併切除が長期生存を可能にしえる治療手段であると述 べているが，自験の成績からは肝合併切除の意義に関 してはいまだ肯定できず，さらに症例を重ねて検討を 
加竞たいと考壳ている.

胃癌の非切除例に対する姑息手術の延命効果に関し

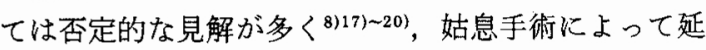
命が得られるとの報告は見当らない。自験例において も平均生存期間は単開腹 4.1 力, 造瘦術 4.3 月 月であ り, $3 \cdot 6 \cdot 9$ 力月生存率は単開腹 $57.1 \% \cdot 19.0 \%$ ・ $4.8 \%$, 造瘻術では $41.7 \% \cdot 16.7 \% \cdot 8.3 \%$ で, 両者の 間に差は認められず，造瘦術には延命効果は得られて いなかった。術死率に関しては, 単開腹では22例中 1 例 $4.5 \%$ ，造㾇術例では 13 例中 1 例 $7.1 \%$ であり，有意 な差はみられなかったが，造瘦術に若干術死率が多 かった，造瘦術には延命効果は期待し難いが，一時的 にも摂食が可能になったり，経腸栄養ができるといら 大きな意義があるが，若干術死率が高いことより造瘦 術を行う場合は慎重に手術操作を行う必要があり，切 除可能であるのに肝転移があるからといって容易に造 瘦術を行うべきではないと思われる。

同時性肝転移胃癌に対する化学療法に関する報告は 多く，一般に原発巣を切除した上で化学療法を行ら意 義は大きいとされている.奥山ら ${ }^{16}$ は化学療法例に $\mathrm{H}_{3}$ 例が多かったにもかかわらず，切除単独例上り有意に 予後は良好であったと述へ，また伊藤 ${ }^{10)}$ は胃切除に化 学療法併用例は非併用例より 1 年生存率の向上がみら れたが，非切除例では予後の向上はみられなかったと 報告している.自験例でも同様な結果が得られていた。 寸なわち非切除例には化学療法による延命効果が全く 認められなかったが，切除例の化療例は非化療例上り 予後不良と考光られる因子が多かったにもかかわら ず,化療例の転帰は非化療例よりも有意に良好であり， 原発巣を切除した上で化学療法を行ら意義は大きいと

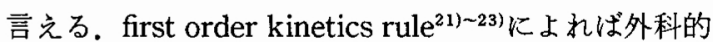
切除により癌細胞数を减少させて化学療法を行った場 合は減少させずに化学療法を行った場合よりもはるか に少数の癌細胞が宿主に残存することになり，さらに 術後に遺残した転移巣は薬剤に対する感受性が増 す24) 27)ことが推定されており，これらの現象があい まって同時性肝転移胃癌に対する原発巣切除に化学療 法を併用した場合に延命が得られる背景をなしている すのと思われる。

自験の化学療法は $\mathrm{MF}\left(\mathrm{F}^{\prime}\right)$ 療法の最低基準を設定 してその効果を検討した。原発巣切除・肝転移巣非切 除・化療例20例の5ち，投与経路は MF 肝動注を含む $\mathrm{MF}\left(\mathrm{F}^{\prime}\right)$ 例は 1 例, $\mathrm{MMC}$ 肝動注 $\mathrm{MF}\left(\mathrm{F}^{\prime}\right)$ 全身投与 例は 2 例， $M F\left(F^{\prime}\right)$ 全身投与例は 9 例であり，症例不
足で投与経路例の治療成績の比較は困難であった。同 時性肝転移胃癌に対して, 肝動注療法が全身化学療法 より延命効果といら点で優れているとの報告は少ない が，肉眼的に確認できるような大きさの肝転移の血行 支配は肝動脈支配が優位であること, 肝動注療法で抗 腫瘍効果が得られやすいこと, 自験の長期生存例 3 例 中 2 例は肝動注併用例であったことにより，同時性肝 転移胃癌では肝動注を含む全身の化学療法により延命 が期待できると思われる。最近では，著者らは原則と して同時性肝転移胃癌に対して少なくとも原発巣を切 除した上で，入院中にMMCに上る肝動注療法と免疫 療法（OK-432）を主体的に行い，退院後は5FU， Tegaful 又はUFT を経口で OK-432 5KE/week 皮内 投与, 並びに $\mathrm{MMC} 6 \mathrm{mg} / \mathrm{m}^{2} / 1$ カ月〜 2 力月ょりなる 長期免疫化学療法 OK-MF (MF') 療法を行ら方針を とっている。転移性肝腫瘍に対しても塞栓化学療法 (Chemoembolization)が盛んに試みられ，一部で延命 効果が報告され始めている28)299. 著者らも最近試みて いるがいまだその廷命効果を確認できる症例に遭遇し ていないが，さらに症例を重称て検討したいと考えて いる.

\section{結語}

同時性肝転移胃癌74例の治療法と転㷌（生存率・生 存率曲線・平均生存期間）との関連を検討し，次のと 抢りの結果と結論を得た。

1) 手術単独の非化療例で非切除例 $(n=14)$ 々原発 巣切除・肝転移巣非切除例（n=16）の転帰を比較する と, 後者の生存率曲線は前者より良好な傾向 (Generalized Wilcoxon test $z=1.81, p<0.1 ）$ があり，後者の 9 力月生存率 $31.3 \%$ は前者の $0 \%$ 上り有意に（p< $0.05 ）$ 良好で，平均生存期間も後者 5.8 力月，前者 3.2 カ月と後者が有意に $(\mathrm{p}<0.05)$ 良好であった。しかし， 非切除例に $\mathrm{S}_{3}$ 之 $\mathrm{P}(+)$ が切除例よりも多い傾向が あった。

2) 肝転移巣合併切除例 (いずれも $\left.\mathrm{H}_{1}, \mathrm{n}=5\right)$ と肝転 移巣非切除の $\mathrm{H}_{1}$ 例 $(\mathrm{n}=4)$ との転帰の間に有意な差は 認められなかった。

3）非切除例では単開腹 $(n=21)$ と造瘦術 $(n=12)$ の $3 \cdot 6$ 力月生存率はそれぞれ $57.1 \% \cdot 19.0 \%$, $41.7 \% \cdot 16.7 \%$, 平均生存期間はそれぞれ 4.1 月・ 4.3 カ月であり，また化療例 $(\mathrm{n}=19)$ と非化療例 $(\mathrm{n}=14)$ の $3 \cdot 6$ 力月生存率はそれぞれ $52.6 \% ・ 26.3 \%$, $50.0 \% \cdot 7.1 \%$ ，平均生存期間はそれぞれ 5.0 力月・3.2 カ月であり, 単開腹と造㾇術, ならびに化療例と非化 
療例の間の転帰に有意な差は認められず，背景因子に も有意な差は認められなかった。

4) 肝転移巣非合併切除例に括いては，化療例 $(n=$ 20) と非化㞠例（ $n=16 ）$ の間に肝転移・腹膜播種性転 移・リンパ節転移程度の分布に差はなかったが，化療 例に $\mathrm{S}_{3}$ 症例が有意に $(\mathrm{p}<0.05)$ 多かった. しかし, 化 療例の生存率曲線は非化療例より有意に(Generalized Wilcoxon test $z=2.12, \mathrm{p}<0.05)$ 良好であった.

5）術後 4 年以上の長期生存例は 3 例 $(4.1 \%, 3 / 74)$ で全例肝転移巣非合併切除・化療 (MF-MF')例ですり, 肝転移巣非合併切除・化㞠例の $15.0 \%(3 / 20)$ 飞相当 し, 非切除例には長期生存例はなかった。

以上の結果より, 非切除例では造瘦術を行っても化 学療法を行っても延命は期待し難く, 肝転移を伴ら胃 癌に対しては積極的に原発巣を切除した上で化学療法 を行ら方針をとれば治療成績が向上すると考学られ る.

\section{文献}

1) 胃癌研究会編：胃癌取扱い規約. 改訂11版, 東京, 金原出版, 1985

2) 西 満正, 田村竜男 : 肝転移胃癌の臨床的研究。癌 の臨 $8: 433-446,1962$

3）植 哲夫：外科的立場からみた癌の転移と再発. 癌の臨 7:642-648, 1961

4）白鳥常男, 中谷正紀，高橋精一ほか：肝転移胃癌の 予後. 日消外会誌 $9: 811-815,1976$

5）葛西洋一：転移肝癌。現代外科学大系 $38 \mathrm{~B}$ 。中山書 店, 東京, p139-142, 1971

6).三上二郎：肝癌の根治手術とその成績. 最新医 $11: 7-9,1956$

7）崒 勝, 原田 稔, 東 昭武注か：胃癌の肝転移 に関する研究. 日外会誌 $62: 1438-1440,1961$

8）星野智雄：胃癌の姑息手術について。癌の臨 4： 423-431, 1958

9）中島聡総, 木下 㦑, 中川安房ほか：胃癌の非治痖 手術症例の予後。癌の臨 $20: 317-323,1974$

10）伊藤一二：転移性肝癌に対する外科的化学療法。 癌と化療 $1: 339-346,1974$

11）林 正泰, 吉沢順一, 平井隆三：肝転移を伴う贯癌 症例の検討. 臨外 37：1269-1273，1982

12）小林勝正, 北條度一, 三輪 橴法か：肝転移のある 消化器癌の手術適応一胃癌, 大腸癌について一. 外 科治療 $34: 352-356,1976$

13）伊藤一二：転移性肝癌の治療一肝切除と化学療法 一. 臨外 22:1543-1550，1967

14）樺木野修郎, 寺崎茂広, 植田紘一ほか：肝転移を伴 万胃癌の手術成績。癌の臨 $26: 424-428,1980$

15）中西昌美, 佐野秀一, 葛西洋一：肝転移を伴 5 胃癌
の病態と手術適応。消外 $7: 1529-1533,1984$

16）奥山和明, 磯野可一, 小野田昌一ほか：胃癌肝転移 症例に対する有効な治療法。日癌治療会誌 19 ： $763-769,1984$

17）加藤哲男：胃癌患者に対する姑息手術の予後につ いて. 癌の臨 $9: 256-259,1963$

18) Lawrence $W$, McNeer $G$ : The effectiveness of surgery for palliation of incurable gastric cancer. Cancer $11: 28-32,1958$

19）勝屋弘辰, 小林節昭, 井上正二郎ほか：胃癌手術の 一見解，とく姑息的胃切除術の存在価値につい て. 外科 $17: 319-323,1955$

20) Shahon DB, Horwitz S, Kelly WD: Cancer of the stomach. An analysis of 115 cases. Surgery 39: 204-221, 1956

21) Skipper HE, Schabel FM, Wilcox WS : Experimental evaluation of potentional anticancer agents. XII. On the criteria and kinetics associ. ate with "curability" of experimental leukemia. Cancer Chemother Rep 35:3-111, 1964

22) Griswold DP, Schabel FM, Wilcox WS et al: Sucoess and failure in the treatment of solid tumors. 1. Effects of cyclophosphamide (NSC. 26271) on primary andmetastatic plas. macytoma in the hamater. Cancer Chemother Rep $52: 345-388,1968$

23) Laster WR, Mayo JG, Simposon-Herren L et al: Cusocess and failure in th treatment of solid tumors. 11. Kinetic parameters and "cell cure" of moderately advanced carcinoma 755 . Cancer Chemother Rep 53:169-188, 1969

24) Simpson-Herren L, Sanford AH, Halmquist JP et al: Effects of surgery on the cell kinetics of residual tumor. Cancer Treat Rep 60:1749 $-1760,1976$

25) Gunduz N, Fisher B, Saffer EA: Effects of surgical removal on the growth and kinetics of residual tumor. Cancer Res $39: 3861-3865$, 1975

26) Valeriote F, Putten L: Proliferative-dependent cytotoxicitt of anticancer agents: A review. Cancer Res $35: 2619-2630,1975$

27) Schenken L: Proliferative charactor and growth modes of neoplastic disease as determinants of chemotherapeutic efficacy. Cancer Treat Rep $60: 1761-1776,1976$

28）伊藤順造, 高橋俊雄, 加藤哲郎注か：肝転移に対す るマイトマイシン・マイクロカプセル動注療法の 臨床効果について。秋田医 $8: 323-331 ， 1982$

29）梶原勇喜, 岡村 純, 堸川真一ほか：胃癌肝転移の transcatheter arterial embolization (TAE) 一 $\mathrm{TAE}$ 後肝切除を行った 1 治験例. 外科治療 $48: 132-135,1983$ 